Терпугов Александр Александрович

начальник факультета заочного обучения Краснодарского университета Министерства внутренних дел Российской Федерации

\section{УЧИТЕЛЬ КАК АГЕНТ СОЦИАЛИЗАЦИИ. К ВОПРОСУ О ПОДРОСТКОВОЙ ПРЕСТУПНОСТИ В РОССИИ}

\section{Аннотация:}

В фокусе научного интереса автора - учитель как агент социализации подрастающего поколения россиян, действующий в пространстве отечественной школы. Опираясь на данные социологического исследования, проведенного на территории города Краснодара и Краснодарского края 6 2018 г., автор приходит к выводу, что большинство респондентов предпочитают общаться с учителями исключительно по вопросам, связанным с изучаемыми дисциплинами и текущими событиями школьной жизни (олимпиады, соревнования, кружки и т. д.), тогда как лишь немногие готовы делиться с учителем свочми проблемами в надежде получить ответ. В заключение утверждается, что отсутствие личностного взаимодействия делает приоритетным для учащейся молодежи подростковое общество, в рамках которого происходит неизбежная девиация как первопричина подростковой преступности.

\section{Ключевые слова:}

учитель, подросток, социализация, межличностное взаимодействие, девиация, преступность, подростковая преступность.
Terpugov Aleksandr Aleksandrovich

Head of the Extramural Department Krasnodar University of the Ministry of Internal Affairs of the Russian Federation

\section{TEACHER AS AN AGENT OF SOCIALIZATION. CONCERNING JUVENILE DELINQUENCY IN RUSSIA}

Summary:

The study focuses on the teacher as an agent of socialization of the younger Russian generation operating in the domestic school. Based on the sociological research conducted in Krasnodar and Krasnodar Territory in 2018, the author reveals that most respondents prefer to communicate with teachers to discuss the subject issues and current events of school life (skills contest, competitions, clubs) while only a few interviewees are ready to share their problems with a teacher hoping to get an answer. In conclusion, it is argued that the lack of personal interaction makes the teenage society the priority in relation to students where the inevitable deviation is the prime cause of juvenile delinquency.

Keywords:

teacher, teenager, socialization, interpersonal interaction, deviation, crime, juvenile delinquency.

Как свидетельствуют отечественные ученые, одной из проблем, инициирующих подростковую преступность, становится отсутствие перспективной для юношества цели. Другими словами, характерное для подросткового возраста девиантное поведение возникает не столько в связи с отсутствием либо слабостью воли, сколько вследствие отсутствия либо неопределенности цели [1, с. 201].

Солидаризируясь с Л.С. Выготским в том, что именно «целевая воля» «дает возможность человеку управлять собой и своим поведением, ставя ему определенные задачи и направляя его процессы так, чтобы они способствовали их эффрективному решению» [2, с. 168], подчеркнем важность следующего момента. По сути, не что иное, как «целевая воля, господствующая над аффректом, овладение собственным поведением, управление собой, умение ставить цели своему поведению и достигать их - вот то, что лежит в основе развития всех психических функций в этом возрасте» [3]. В данном контексте становится очевидным, что именно наличие или отсутствие жизненного плана у молодого поколения россиян позволяет судить как о степени его инфантильности, так и о мере взрослости.

Поскольку среда, в которой происходит формирование личности подростка, в том числе его ориентаций на будущее, определяется пространством школы, нельзя не признать особую роль учителя как одного из главных агентов социализации. Однако, учитывая, что, нацеленный на успешную сдачу ЕГЭ своими подопечными, учитель все свои творческие силы и педагогический талант вкладывает в процесс обучения, нельзя не признать, что в действительности такой уподобляемый «натаскиванию» учащейся молодежи на конкретный результат процесс мало отвечает долговременной перспективе, достижение которой невозможно вне упомянутого жизненного плана. Свидетельство тому - гарантированная государством возможность подать документы в несколько вузов, чтобы подстраховаться и непременно поступить хотя бы в один из них. Понятно, что существующая «лотерея» не имеет ничего общего с преодолением самых разных препятствий для осуществления задуманного, тем более что изначально существующие альтернативы снимают остроту проблемы. 
Принимая во внимание тот фракт, что «известное напряжение, существование препятствий... является необходимым условием для поддержания интереса к будущему, стремлением на встречу с которым, по сути, и определяется целевая воля» [4, с. 142], с неизменностью угасающая в случае отсутствия требующих волевого усилия обстоятельств, понятно, почему, даже оказавшись в вузе, молодые люди живут по инерции, ничего не желая либо не умея разобраться в том, чего они хотят на самом деле, нередко оказываясь во власти инстинктов. Неслучайно поэтому половая распущенность, приводящая к всевозможным отклонениям, становится приметой современной действительности. Как писал С.С. Аверинцев, «целомудрие - культура воли, школа собственного достоинства, школа самоуважения» [5, с. 45].

Вместе с тем, помимо особых условий, продиктованных объективными обстоятельствами, связанными со взятым отечественным образованием курсом на ЕГЭ, сам учитель оказался незащищенным перед требованиями времени, отмеченными формализацией, рутинизацией и бюрократизацией профессиональной педагогической деятельности, что влечет за собой подчас необратимые процессы. В их числе личностная деструкция, девиантное поведение, профессиональный кретинизм. Тем не менее, оставаясь в стенах российской школы, такой учитель вынужден осуществлять взаимодействие с учащейся молодежью, что создает прецедент, суть которого с наибольшей полнотой раскрывает следующая мысль: юноши и девушки становятся правонарушителями или «ненормальными» вследствие «правонарушительной» или «ненормальной» педагогики [6].

В целом о качестве отношений учителя и учащихся в период получения школьного образования можно судить на основе результатов проведенного нами в 2018 г. в Краснодаре и Краснодарском крае социологического исследования (общее количество респондентов - 873 человека).

В частности, ответы на вопрос: «Часто ли ты просишь совета или помощи по вопросам, не связанным со школьными предметами, у учителей?» - распределились следующим образом. Иногда обращаются за советом или помощью менее половины учеников 5-х классов (43 \%) и лишь немногие ученики 6-х (17), 7-х (10), 8-х (5), 10-х (25) и 11-х классов (7 \%). Количество респондентов, обращающихся к своим школьным наставникам очень редко, возрастает к выпускному классу. Так, если в 5-х классах таких учеников незначительное количество (14 \%), то в 9, 10, 11-х классах их половина от общего числа опрошенных. Количество респондентов, которые никогда не обращаются к своим учителям за помощью и советом, не связанными с освоением школьной программы, варьируется в пределах от 17 \% в 6-х классах до 67 \% в 8-х классах.

Нельзя не заметить следующую закономерность: чем старше становятся ученики, тем реже они обращаются к учителям за советом, помощью по вопросам, не связанным со школьными дисциплинами. Данный факт может быть истолкован двояко. Во-первых, взрослея, подростки приобретают личный опыт, позволяющий им самостоятельно решать жизненные проблемы, не прибегая к помощи учителя. Во-вторых, в процессе взаимодействия с учителями подростки могут получить негативный опыт, мотивирующий их на дальнейший отказ от обращения к учителям.

На открытый вопрос: «Если ты просишь совета или помощи, объясни почему?» - получены следующие ответы учеников 5-го класса: «обращаюсь по вопросам, связанным с учебными дисциплинами, школьной жизнью (расписание тренировок, олимпиад, непонятен материал и т. д.)»88 \%; «обращаюсь, когда нужна помощь в разрешении конфликтов, нарушении личных прав (оскорбляют, обижают сверстники)» - $12 \%$.

К числу ответов учеников 6-го класса, повторяющихся с наибольшей частотой, относятся следующие: «обращаюсь к учителям “из принципа"» - 33 \%; «обращаюсь, потому что доверяю учителям и уважаю их мнение» - 33 \%; «не доверяю учителям» - $34 \%$.

Ответы учащихся 7-го класса распределились несколько иначе: 70 \% опрошенных обращаются только по школьным дисциплинам; 13 \% стесняются, не желая быть опозоренными, попасть в неловкую ситуацию; 10 \% не доверяют в жизни никому, кроме себя; 7 \% ценят мнение учителя.

Для учащихся 8-го класса характерен следующий результат: 76 \% обращаются только по школьным дисциплинам; по 8 \% не доверяют в жизни никому, кроме себя; ценят мнение учителя; стесняются быть опозоренными, попасть в неловкую ситуацию.

Ответы учащихся 9-го класса складываются в следующую картину: 75 \% обращаются только по школьным дисциплинам; 20 \% решают все вопросы сами; 5 \% никому не доверяют, кроме учителя.

Ответы учеников 10-го класса следующие: «обращаюсь только по вопросам, связанным со школьной жизнью» - 75 \%; «дома поговорить не с кем» - $25 \%$.

Наконец, ответы учащихся 11-го класса оказались следующими: «обращаюсь только по вопросам, связанным со школьной жизнью» - 86 \%; «решаю все вопросы сам» и «доверяю не всем, только классному руководителю» $-7 \%$.

Полученные данные позволяют сделать вывод, что большинство респондентов предпочитают общаться с учителями исключительно по вопросам, связанным с изучаемыми дисциплинами и текущими событиями школьной жизни (олимпиады, соревнования, кружки и т. д.). Лишь немногие готовы делиться остальными проблемами или спрашивать совета у учителей. 
Половина опрошенных подростков старших классов считает, что учителя относятся к ним как к детям. Примечательно, что если доля школьников, не задумывавшихся об отношении к ним учителей, в 5-м классе составляла $69 \%$, то к 11-му классу таких остается лишь $10 \%$. Таким образом, очевиден личностный рост школьников, обусловленный постижением мира через статусно-ролевую («ребенок - взрослый») систему отношений.

Еще один вопрос, который высвечивает специфику школьного учителя, выступающего в качестве агента социализации, был связан с выявлением реакции учителей на активность учеников в жизни школы посредством высказывания личных идей и пожеланий, направленных на то, чтобы сделать ее интереснее. Так, вариант ответа «учителя меня выслушивают и стараются помочь реализовать идеи в жизни» отметили около трети респондентов 5-х классов (31 \%). К 11-му классу доля тех, чьи идеи принимаются во внимание, снижается до 21 \%. Менее половины учеников 5-х классов (44 \%) отмечают, что их идеи по улучшению школьной жизни принимаются во внимание. По мнению некоторых учеников 11-х классов (7 \%), их идеи и предложения вообще никогда не учитываются.

Обосновывая собственную позицию, большинство респондентов были солидарны в отсутствии желания и стремления предлагать какие-либо идеи по улучшению школьной жизни. Полученные результаты, на наш взгляд, свидетельствуют о том, что к выпускным классам социальная активность, инициативность школьников снижается. Подобное положение дел можно трактовать, с одной стороны, как перенаправление индивидуальных усилий со школьной жизни на посторонние занятия, с другой - как отсутствие поддержки инициативности подростков со стороны учителей и школьной администрации. Данная версия коррелирует с распространенной общественной позицией, что современная школа «самоустранилась», «не воспитывает», «оказывает образовательные услуги», а также с заключениями современных ученых, что снижение гражданской активности молодого поколения россиян становится на сегодняшний день объективным фактом [7, с. 164-165].

Принимая во внимание обстоятельство, согласно которому подросток, испытывающий потребность познать и понять себя как личность, обладающую только ей присущими качествами [8], в случае неудовлетворительного решения данной проблемы будет вести себя агрессивно, вполне закономерной становится следующая ситуация. Зачастую, отвергая авторитет учителя, чья профессиональная опека видится мелочной и вызывает лишь раздражение, подросток будет искать понимания в среде таких же, как и он сам, подростков. Имеется в виду неизбежная в этом случае «переориентация общения подростка с родителей, учителей и вообще старших на ровесников» [9], что на данный период становится его главной жизненной ценностью. Это связано с тем, что именно социальная позиция в классе становится знаком социального благополучия либо неблагополучия. Помимо этого, неприятие индивида представителями референтной группы, «негативные взаимоотношения с другими, иначе говоря, взаимоотношения, в которых индивида не воспринимают так, как ему... хотелось бы, чтобы его воспринимали» [10] являются фрактором, порождающим аномическое напряжение на уровне личности.

Поскольку соответствие той или иной подростковой группе требует от каждого из ее членов некоторой доли конформизма [11], потребность принадлежности к большинству приводит к доминированию «стадного чувства» над индивидуальным сознанием. Об этом пишет Г. Лебон: «Каковы бы ни были индивиды, составляющие массу, каков бы ни был их образ жизни, занятия, их характер или ум, одного их превращения в толпу достаточно для того, чтобы у них образовалось нечто вроде коллективной души, заставляющей их чувствовать, думать и действовать совершенно иначе, чем думал бы, действовал и чувствовал каждый из этих людей в отдельности» [12].

Более того, становясь частью целого, подросток с неизбежностью отказывается от необходимости сдерживать свои природные инстинкты. При этом то́, что он нередко принимает в себе за проявление своей индивидуальности, связывая с новыми, обретенными в окружении «друзей» чертами характера, на самом деле оказывается абсолютно противоположным. Нечто, прежде глубоко спрятанное, выходит на поверхность, являя все самое негативное, что могут таить в себе долго сдерживаемые природные импульсы.

Подчеркнем, в ситуации, когда отдельные подростки собираются в группу, не имея какойлибо высокой цели, все, что было под запретом, стремительно выплескивается наружу. Вследствие этого у некоторых из них появляется потребность в насилии, жестокости, а у других, напротив, возникает стремление проявить героизм со свойственным первобытным людям энтузиазмом. В обоих случаях налицо фракт собственно девиантного поведения, которое при неблагоприятных условиях социализации способно переродиться в преступное. Само же правовое сознание подрастающего поколения, имеющее в данный период активную фазу, оказывается под действием комплекса объективных и субъективных факторов. Последние в свою очередь детерминированы физиологическими и психологическими особенностями описываемого возрастного периода [13, с. 149]. 
Призванная выступать одним из главных агентов процесса социализации российская школа в лице учителя недостаточно справляется с закрепленной за ней миссией, что не только не позволяет минимизировать подростковую преступность в России, но и во многом инициирует необходимость внесения на рассмотрение в Думу законопроекта, согласно которому возраст наступления ответственности за противоправные действия снижается с 14 до 12 лет.

\section{Ссылки:}

1. Толстых Н.Н. Хронотоп: культура и онтогенез : монография. М., 2018. 292 с.

2. Выготский Л.С. Детская психология // Выготский Л.С. Собрание сочинений : в 6 т. М., 1984. Т. 4. 432 с.

3. Там же.

4. Выготский Л.С. Педология подростка. М., 1929. 172 с.

5. Аверинцев С.С. Попытка объясниться. М., 1988. 48 с. (Библиотека «Огонек». № 13).

6. Цит. по: Невская С.С. А.С. Макаренко о педагогическом взаимодействии семьи и школы [Электронный ресурс] // Порталус. Научная цифровая библиотека. 2007. 23 окт. URL: http://portalus.ru/modules/shkola/rus_readme.php?subaction=showfull\&id=1193142045\&archive=1195596785\&start from=\&ucat=\& (дата обращения: 15.07.2018).

7. Гусарова М.А. Некоторые аспекты фрормирования гражданской активности будущих юристов // Наука и образование: хозяйство и экономика; предпринимательство; право и управление. 2012. № 4 (23). С. 162-164.

8. Божович Л.И. Личность и ее формирование в детском возрасте. СПб., 2008. 398 с.

9. Кон И.С. Психология ранней юности. М., 1989. 256 с.

10. Agnew R. Foundation for a General Strain Theory of Crime and Delinquency // Criminology. 1992. Vol. 30, no. 1. P. 47-88. https://doi.org/10.1111/j.1745-9125.1992.tb01093.x.

11. Реан А.А. Психология личности. Социализация, поведение, общение. СПб. ; М., 2004. 407 с.

12. Лебон Г. Психология толп. М., 1999. 416 с.

13. Гусарова М.А. Особенности правовой социализации современной российской молодежи в период аномизации // Общество: политика, экономика, право. 2011. № 3. С. 149-153.

\section{References:}

Agnew, R 1992, 'Foundation for a General Strain Theory of Crime and Delinquency', Criminology, vol. 30, no. 1, pp. 47-88. https://doi.org/10.1111/j.1745-9125.1992.tb01093.x.

Averintsev, SS 1988, Trying to explain yourself, Moscow, 48 p., (in Russian).

Bozhovich, LI 2008, Personality and its development in childhood, St. Petersburg, 398 p., (in Russian).

Gusarova, MA 2011, 'Features of legal socialization of contemporary Russian youth in the period of anomization', Society: politics, economics, law, no. 3, pp. 149-153, (in Russian).

Gusarova, MA 2012, 'Several aspects of developing the civic engagement of future lawyers', Nauka i obrazovaniye: khozyaystvo i ekonomika; predprinimatelstvo; pravo i upravleniye, no. 4 (23), pp. 162-164, (in Russian)

Kon, IS 1989, Psychology of early adolescence, Moscow, 256 p., (in Russian).

Lebon, G 1999, Psychology of crowds, Moscow, 416 p., (in Russian).

Nevskaya, SS 2017, 'A.S. Makarenko on the educational interaction between the family and the school', Portalus. Nauchnaya tsifrovaya biblioteka, 23 Oct., viewed 15 July 2018, <http://portalus.ru/modules/shkola/rus readme.php?subaction=showfull\&id=1193142045\&archive=1195596785\&start_from $=\& u c a t=\&>$, (in Russian).

Rean, AA 2004, Psychology of Personality. Socialization, behavior, communication, St. Petersburg, Moscow, 407 p., (in Russian).

Tolstykh, NN 2018, Chronotope: culture and ontogeny: monograph, Moscow, 292 p., (in Russian).

Vygotsky, LS 1929, Pedology of the adolescent, Moscow, 172 p., (in Russian).

Vygotsky, LS 1984, Children's psychology, collected works, in 6 vols., Moscow, vol. 4, 432 p., (in Russian). 